Вісник Харківського національного університету імені В.Н. Каразіна Серія "Математика, прикладна математика і механіка" Том 90,2019 , с. $42-59$

УДК $532.529+577$
Visnyk of V.N.Karazin Kharkiv National University Ser. "Mathematics, Applied Mathematics and Mechanics"

Vol. 90, 2019, p. 42-59

DOI: $10.26565 / 2221-5646-2019-90-03$

\title{
Mathematical modeling of particle aggregation and sedimentation in the inclined tubes
}

\author{
V. Baranets, N. Kizilova \\ V. N. Karazin Kharkiv National University \\ Svobody sqr., 4, 61022, Kharkiv, Ukraine \\ cherevko.vita@gmail.com, n.kizilova@gmail.com
}

Sedimentation of the aggregating particles of different technical suspensions, blood and nanofluids in the gravity is investigated. The dependence of the sedimentation rate on the angle of inclination is considered. The two phase model of the aggregating particles is generalized to the inclined tubes. In the suggestion of small angles of inclination the equations are averaged over the transverse coordinate and the obtained hyperbolic system of equations is solved by the method of characteristics. Based on the results, a novel method of estimation of the suspension stability is proposed.

Keywords: Boycott effect; suspension; aggregation; sedimentation; medical diagnostics.

Баранець В. О., Кізілова Н. М. Математичне моделювання агрегації та осідання частинок в похилих трубках. Досліджується осідання агрегуючих частинок різних технічних суспензій, крові і нанорідин в умовах сили тяжіння. Розглядається залежність швидкості осідання від кута нахилу. Двофазна модель агрегуючих частинок узагальнена для випадку похилих трубок. У припущенні малих кутів нахилу рівняння усереднюються по поперечній координаті, а отримана гіперболічна система рівнянь розв'язується методом характеристик. На основі отриманих результатів запропоновано новий метод оцінки стійкості суспензії.

Ключові слова: ефект Бойкотта; суспензія; агрегація; седиментація; медична діагностика.

Баранец В.А., Кизилова Н.Н. Математическое моделирование агрегации и оседания частиц в наклонных трубках. Исследуется оседание агрегирующих частиц различных технических суспензий, крови и наножидкостей в условиях силы тяжести. Рассматривается зависимость скорости оседания от угла наклона. Двухфазная модель агрегирующих частиц обобщена для случая наклонных трубок. При предложении малых углов наклона уравнения усредняются по поперечной координате, а полученная гиперболическая система уравнений решается методом характеристик. На основании полученных результатов предложен новый метод оценки устойчивости суспензии.

Ключевые слова: эффект Бойкотта; суспензия; агрегация; седиментация; медицинская диагностика.

2010 Mathematics Subject Classification: 76T20, 76Zxx, 83C55.

(c) V.Baranets, N. Kizilova, 2019 


\section{Introduction}

Influence of inclination of the vessel in which a suspension of particles sediments in the gravity field was first discovered by Arthur Boycotte in 1920 on the red blood cell (RBC) sedimentation in thin long vertical tubes [1], and now it is known as the Boycotte effect. On that time the RBC sedimentation test was recognized as the most powerful medical diagnostic means on general pathology, and many researchers were seeking for more benefit test conditions, including the usage of the inclined tubes. This sedimentation technique is also widely used for the waste water cleaning, drinking water purification, treatment of mixtures in industry and manufacture, and the high reservoirs or deep wells are needed for the successful processing. The settling of particles in the high containers is limited by its width, and tilting of the reservoir or well increases the efficient area of sedimentation, decreases the distance that each particle must travel before impacting a wall, and, therefore, enhances the sedimentation rate in orders of magnitude [2].

The Boycotte effect is used in the oil industry because at certain inclination angles $(40-50)^{\circ}$ of the tube the clearest separation of the suspension for oil-well cementation is observed [3]. The effect is also used for mixing of the granular matters [4]. It may be responsible for specific sediment distribution along inclined ocean bottom at the water stratification conditions [5], and for the pattern formation at the inclined surfaces of the sand-dunes [2]. All suspensions settle faster in the inclined vessels and exhibit clear separation of the layers of different optical density, but the problem on determination of the optimal angels remains still unsolved.

\section{Review of theoretical and experimental data}

Experimental studies of the Boycott effect on suspensions containing light and heavy particles with concentrations $\mathrm{C}_{l}, \mathrm{C}_{h}$ in inclined channels revealed a significant influence of the inclination angle on the particle separation along the inclined wall and the lateral fingering phenomena [6]. For each set of the concentrations

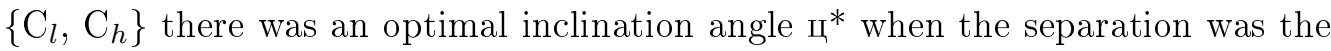
clearest and at the bigger angles $\rangle_{\Perp} *$ it was blocked. The dependence ${ }^{*}\left(\mathrm{C}_{l}, \mathrm{C}_{h}\right)$ was found quite complex.

A complex dependence of the RBC sedimentation rate $\mathrm{h}$ on the tilt angle и has been demonstrated in numerous experimental studies. The value $\mathrm{h}$ is measured as the height of clear serum in the top part of the sedimentation tube (Fig.1a,b). The experiments on the RBC suspensions with concentrations $C=(10-50) \%$ and the tilt angles $u=(0-80)^{\circ}$ revealed the approximation of the sedimentation curves in the form $h(t)=a(1-\exp (-b t))$, where $a(\theta)$ is an increasing function, $b(\theta)=k \sin (\theta), k \approx$ const [7].

Based on the continuum mechanics approach, it was shown [8] that the sedimentation rate in the rectangle tank is determined by the Reynolds number Re 
and the parameter $\Lambda$ which is the ratio of the sedimentation Grashof number to Re:

$$
R e=\frac{\rho_{f} H u_{0}}{\mu_{f}}, \quad \Lambda=\frac{\left(\rho_{s}-\rho_{f}\right) H^{2} g C_{0}}{u_{0} \mu_{f}},
$$

where $\rho_{s}$ and $\rho_{f}$ are densities of the solid and fluid materials, $\mu_{f}$ is the fluid viscosity, $C_{0}$ is the concentration of the particles, $g$ is the acceleration of gravity, $u_{0}$ is the characteristic sedimentation rate of a single particle with diameter $a$ in the fluid, that can be estimated by the Stokes formula [9]

$$
u_{0}=\frac{2\left(\rho_{s}-\rho_{f}\right) a^{2} g}{9 \mu_{f}} .
$$

Using (2), (1) can be rewritten as

$$
R e=\frac{2 \rho_{f}\left(\rho_{s}-\rho_{f}\right) H a^{2} g}{9 \mu_{f}^{2}}, \quad \Lambda=\frac{9 C_{0}}{2}\left(\frac{H}{a}\right)^{2} .
$$

At low Re numbers the values $\Lambda$ are high, and in the limit $\Lambda \rightarrow \infty$ the rate $\mathrm{Q}$ of the clear solvent production (layer I in Fig.1a,b) can be described by the kinematic Ponder-Nakamura-Kuroda (PNK) formula [10, 11]

$$
Q=u_{0} f(C) B(\cos (\theta)+\tan (\theta) H / B),
$$

where the function $f(C)$ depends on the particle size, shape, material, surface charge and other properties.

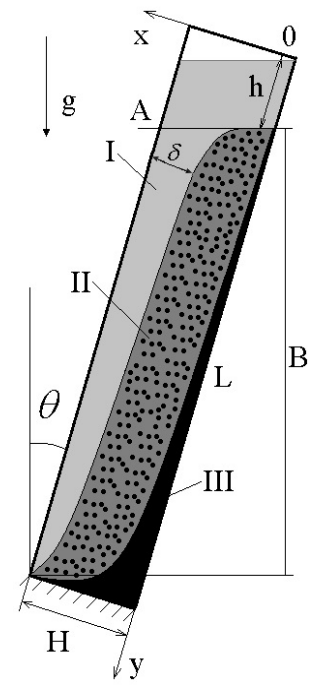

a

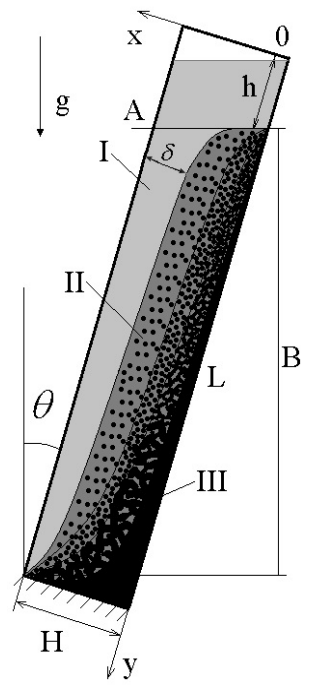

$\mathrm{b}$

Fig.1. A sketch of the particle sedimentation in the inclined tube for the non-aggregating (a) and aggregating (b) particles. 
As one can see from (3), the approach (4) is acceptable when

$$
H \gg a \sqrt{\frac{2}{9 C_{0}}},
$$

that gives for the RBC with $a=5 \cdot 10^{-6} \mathrm{~m}, C_{0}=(35-48) \%$ the unrealistic estimations $H \sim(3.5-4) \cdot 10^{6} \mathrm{~m}$. Besides, the good correspondence of the PNK formula (4) to the experiments has been proven at low concentrations $C_{0} \leq 0.1$ only [2].

The continuum mechanics approach based on the two phase theory was applied to the sedimentation in the inclined vessels in the case of the inviscid [12] and viscous fluid [13]- [15]. Based on these studies, the division into three sedimentation zones (clear fluid (I), suspension (II), and sediment (III), Fig.1a) has been proposed. The boundary layer approach has been used to determine the velocity profiles in the zonez I-III [8]. In the case of the non-aggregating hard spheres the mixture theory gave the following formulae [8]:

$$
\delta=\left(\frac{2 a^{2} U \tan (\theta y)}{3 C_{0} u_{0}}\right)^{1 / 3}, \quad V=\frac{9 \delta^{2} C_{0} u_{0} \cos (\theta)}{2 a^{2}}\left(\frac{x}{\delta}-\frac{x^{2}}{2 \delta^{2}}\right),
$$

where $U$ is the sedimentation rate of the same suspension in the vertical tube.

The experimental studies on the non-aggregating $\mathrm{RBC}$ revealed that the layer I begins to be formed after $\mathrm{t}=8$ and $1.8 \mathrm{~min}$ at the tilt angles $\theta=10^{\circ}$ and $\theta=40^{\circ}$ accordingly [16]. The width $\delta_{A}$ and the velocity $V_{A}$ measured at the level of the point A (Fig.1a) demonstrated a good agreement with those computed on (6).

Recently the inclined channel technology has been used in the microfluidic applications for blood separation using the centrifugal and Coriolis forces with Zweifach-Fung effect $[17,18]$. In this design the RBC are pushed to the bottom of the curved channel due to the effect of centrifugal and Coriolis forces and then are collected through the bottom channel due to ZP effect, and the blood plasma is collected from the top of the channel.

Therefore, the RBC sedimentation in the inclines vessels is a promising technology for biology, medicine, microfluidic and nanotechnologies, while theoretical description of the system dynamics is confined by non-aggregating suspensions with low concentrations $C_{0}<0.1$, low Reynolds numbers $\operatorname{Re}\langle 1$ and unrealistic high vessels. The dynamics of the ensembles of aggregating particles has been recently studied by Lattice Boltzmann simulations [19]. The results of the study confirmed the existence of global convection motion of the particles and their aggregates that tend to enhance the sedimentation process. It was found, that smaller intermittent vortices, formed from the wakes of groups of settling particles, play an important role in the sedimentation process and the resulting distribution of the particles.

In this paper the continual mechanics approach is used for the sedimentation of the concentrated suspensions of the aggregating particles. It will be shown, the 
settling dynamics in the incline tubes is more complex and the additional sublayers of the sedimenting single particles (IIa), their aggregates (IIb) and the porous viscoelastic layer (IIc) (Fig.1b) will appear during the sedimentation similar to the vertical tube case [20].

\section{Problem formulation.}

The steady sedimentation of particles in the narrow channel of the width $R$ and the length $L(R / L \ll 1)$, inclined at the angle $\theta$ is considered. The channel corresponds to the gap between the walls of the rotation viscosimeter of the conecone type or a rectangle vessel with the depth $D \gg R$. The two phase approach to the suspension of the aggregating particles is used [20,21]. Neglecting the inertia forces as compared with the viscous forces, the equations of the quasi-steady motion can be written in the form

$$
\begin{gathered}
\frac{\partial N}{\partial t}+\frac{\partial}{\partial x} N u_{x}^{1}+\frac{\partial}{\partial y} N u_{y}^{1}=\varphi \\
\frac{\partial H}{\partial t}+\frac{\partial}{\partial x} H u_{x}^{1}+\frac{\partial}{\partial y} H u_{y}^{1}=0 \\
\frac{\partial}{\partial x}\left[H u_{x}^{1}+(1-H) u_{x}^{2}\right]+\frac{\partial}{\partial y}\left[H u_{y}^{1}+(1-H) u_{y}^{2}\right]=0, \\
H \frac{\partial p}{\partial y}=-F\left(u_{y}^{1}-u_{y}^{2}\right)+H \rho_{s} G \cos (\theta), \\
(1-H) \frac{\partial p}{\partial y}=F\left(u_{y}^{1}-u_{y}^{2}\right)+(1-H) \rho_{f} G \cos (\theta), \\
H \frac{\partial p}{\partial x}=-F\left(u_{x}^{1}-u_{x}^{2}\right) H \rho_{s} G \sin (\theta), \\
(1-H) \frac{\partial p}{\partial x}=F\left(u_{x}^{1}-u_{x}^{2}\right)+(1-H) \rho_{f} G \sin (\theta),
\end{gathered}
$$

where $\left(u_{x}^{1}, u_{y}^{1}\right)$ and $\left(u_{x}^{2}, u_{y}^{2}\right)$ are components of the velocity vectors for the particles (phase 1) and fluid (phase 2), (0xy) is the Cartesian coordinate system connected with the $\rho_{s}, \rho_{f}$ are densities of the solid and fluid materials, $p$ is the hydrostatic pressure, $H$ and $N$ are the mass and numerical concentrations of the particles, $F$ is the phenomenological coefficient for the viscous drag forces acting on the particle from the viscous fluid, $\varphi$ the aggregation rate, $G$ is the mass force that can be chosen as $G=n g, n$ is the magnification factor when the sedimentation is carried out in a centrifuge [21].

The equation (7) describes the kinetics of the particle aggregation due to the collisions, decompositions or exchange interactions [20]. The mass continuity conditions for the phases (8), (9) and the projections of the momentum equations 
for the phases on the axis coordinate (10)-(13) give the system of PDE for the velocities, pressures and numerical concentration of the aggregates. The same model in one-dimensional formulation has been used for the RBC sedimentation modeling in the vertical tubes, in thin gaps between the walls of the rotational viscosimeter of the cylinder-cylinder type [22] and in the centrifugal force field [23]. In the two-dimensional formulation it has been applied to the RBC sedimentation in the circular tubes in the external magnetic field [24]. The system (7)-(13) can be solved by numerical methods, but in order to derive more convenient halfanalytical estimations, in this paper a simplified one-dimensional model will be obtained by averaging of the equations (7)-(13) over the transverse coordinate $x$.

\section{One-dimensional approximation for small inclination angles.}

Based on the dimension theory, the expressions for $F$ and $\varphi$ have been found in the form [20], [22] - [24]:

$$
F=\mu_{f} H(1-H)^{-2,5} w^{-2 / 3}, \quad \varphi=-k H^{2} w^{-2},
$$

where $w=H / N$ is the average volume of the aggregates, $k$ is the empirical constant that determines the aggregate formation.

By excluding pressure in (10)-(13) and using the impermeability condition at the bottom of the tube $x=L$, one can obtain

$$
\begin{array}{ll}
u_{x}^{1}=-\Theta(H) \sin (\theta), & u_{y}^{1}=\Theta(H) \cos (\theta), \\
u_{x}^{2}=\frac{H \Theta(H) n g \delta \rho \sin (\theta)}{(1-H) F}, & u_{y}^{2}=-\frac{H \Theta(H) n g \delta \rho \cos (\theta)}{(1-H) F},
\end{array}
$$

where $\Theta(H)=H(1-H)^{2} \delta \rho G / F(H), \delta \rho=\rho_{s}-\rho_{f}$.

When $\theta=0$ (15) coincide with the corresponding expressions for the nonuniform centrifugal force field $n g(x)=a x+b$ acting on the blood cells in vertical tubes [23]. When $\theta=0$ and $n=1$ (15) coincides with the expressions for the gravitational blood sedimentation computed in [21, 22].

Let us assume, the aggregation at the expense of the lateral motion of the particles is essential if during the time $T$ of the particle sedimentation along the distance $L$ their radial displacement $\delta$ will be of the order of magnitude of $R$. Since $\delta \approx\left|u_{x}^{1}\right| T, T \approx L /\left|u_{y}^{1}\right|$, this condition accounting for (15) can be written as

$$
\frac{\delta}{R} \approx \frac{L\left|u_{x}^{1}\right|}{R\left|u_{y}^{1}\right|}=\frac{L}{R} \tan (\theta) .
$$

Let us consider $\delta / R$ as a non-dimensional parameter characterizing the aggregation due to the lateral motion towards the inclined lower wall of the vessel. Since it will result in the faster approaching and aggregation of the particles, this 
parameter must be accounted for in the expression for the aggregation rate (14) in the form [24]

$$
\varphi=-k N^{2} w^{-2}(1+O(\delta / R)) .
$$

For instance, in [23] the following estimation has been used:

$$
\varphi=-\frac{k N^{2}}{w^{2}}\left(1-2 \frac{\delta}{R}+\frac{\delta^{2}}{R^{2}}\right)^{-1} .
$$

As it is follows from (16), the second order term in (18) can be neglected for sufficiently small inclination angles. For instance, in for the laboratory viscosimeters for blood testing the values $L / R \sim(1.7-2.5)$ so at the angles $\theta<10^{\circ}$ the simplifying approach $\delta / R \ll 1$ is valid and $\varphi=-k N^{2}(1+2 \delta) / w^{-2}$ can be accepted.

For the averaging purposes let us introduce the following designations: $x \in\left[0 ; x_{s}\right]$, where $x_{s}$ is the coordinate of the interface between the layers I and IIa (Fig.1b)

$$
\begin{aligned}
& N(t, x, y)= \begin{cases}N(t, y), & x \leq x_{s} \\
0, & x_{s}<x \leq s\end{cases} \\
& H(t, x, y)= \begin{cases}H(t, y), & x \leq x_{s} \\
0, & x_{s}<x \leq s\end{cases}
\end{aligned}
$$

where $s$ is the width or the area occupied by the particles and aggregates (Fig.1b).

According to (15) the interface $x=x_{s}$ between the zones I and IIa moves with the speed

$$
U_{x}=\left.u_{x}^{1}\right|_{x=x_{s}}=H(1-H)^{2} g \delta \rho \sin \alpha F^{-1} .
$$

The averaged values will be introduced in the form

$$
\langle f\rangle=\frac{1}{x_{s}} \int_{0}^{x_{s}} f d x .
$$

Then the system (7)-(13) can be written as

$$
\begin{aligned}
& \frac{\partial}{\partial t}\langle N\rangle+\frac{\partial}{\partial y}\langle N\rangle\left\langle u_{y}^{1}\right\rangle+k\langle N\rangle^{2} \Delta\left(x_{s}, y\right)=\frac{1}{x_{s}} \frac{\partial x_{s}}{\partial t}\left(N\left(t, x_{s}, y\right)-\langle N\rangle\right)+ \\
& +\left\{\frac{1}{x_{s}} \frac{\partial x_{s}}{\partial y}\left(N\left(t, x_{s}, y\right) u_{y}^{1}\left(t, x_{s}, y\right)-\langle N\rangle\left\langle u_{y}^{1}\right\rangle\right)\right\}- \\
& -\frac{1}{x_{s}} N\left(t, x_{s}, y\right) u_{x}^{1}\left(t, x_{s}, y\right),
\end{aligned}
$$




$$
\begin{aligned}
& \frac{\partial}{\partial t}\langle H\rangle+\frac{\partial}{\partial y}\langle H\rangle\left\langle u_{y}^{1}\right\rangle= \\
& =\left\{\frac{1}{x_{s}} \frac{\partial x_{s}}{\partial y}\left(H\left(t, x_{s}, y\right) u_{y}^{1}\left(t, x_{s}, y\right)-\langle H\rangle\left\langle u_{y}^{1}\right\rangle\right)\right\}- \\
& -\frac{1}{x_{s}} H\left(t, x_{s}, y\right) u_{x}^{1}\left(t, x_{s}, y\right)-\frac{1}{x_{s}} \frac{\partial x_{s}}{\partial t}\left(\langle H\rangle-H\left(t, x_{s}, y\right)\right), \\
& \frac{\partial}{\partial t}\left[\langle H\rangle\left\langle u_{y}^{1}\right\rangle+(1-\langle H\rangle)\left\langle u_{y}^{2}\right\rangle\right]= \\
& =\left\{\frac{1}{x_{s}} \frac{\partial x_{s}}{\partial y}\left(H\left(t, x_{s}, y\right) u_{y}^{1}\left(t, x_{s}, y\right)-\langle H\rangle\left\langle u_{y}^{1}\right\rangle\right)\right\}+ \\
& +\left(1-H\left(t, x_{s}, y\right)\right) u_{y}^{2}-(1-\langle H\rangle)\left\langle u_{y}^{2}\right\rangle- \\
& -\frac{1}{x_{s}}\left[H\left(t, x_{s}, y\right) u_{x}^{1}\left(t, x_{s}, y\right)+\left(1-H\left(t, x_{s}, y\right)\right) u_{x}^{2}\left(t, x_{s}, y\right)\right] \\
& \langle H\rangle \frac{\partial}{\partial y}\langle p\rangle+F(\langle H\rangle,\langle N\rangle)\left(\left\langle u_{y}^{1}\right\rangle-\left\langle u_{v}^{2}\right\rangle\right)+\rho_{s} g \cos (\theta)\langle H\rangle= \\
& =\left\{\frac{1}{x_{s}} \frac{\partial x_{s}}{\partial y}\left(H\left(t, x_{s}, y\right) p\left(t, x_{s}, y\right)-\langle H\rangle\langle p\rangle\right)\right\}, \\
& (1-\langle H\rangle) \frac{\partial}{\partial y}\langle p\rangle-F(\langle H\rangle,\langle N\rangle)\left(\left\langle u_{y}^{1}-u_{y}^{2}\right\rangle\right)+\rho_{f} g \cos (\theta)(1-\langle H\rangle)= \\
& =\left\{\frac{1}{x_{s}} \frac{\partial x_{s}}{\partial y}\left((1-\langle H\rangle)\langle p\rangle-\left(1-H\left(t, x_{s}, y\right)\right) p\left(t, x_{s}, y\right)\right)\right\},
\end{aligned}
$$

The system could be significantly simplified when $\partial x_{s} / \partial y=0$. Since in the general case $\partial x_{s} / \partial y \neq 0$, let us estimate the terms in the right hand sides of (22)(26). In the zones I and II we have the following expressions:

$$
\begin{aligned}
& \frac{\partial p}{\partial x}=\left[H\left(t, x_{s}, y\right) \rho_{S}+\left(1-H\left(t, x_{s}, y\right) \rho_{f}\right)\right] g \sin (\theta) \quad\left(0 \leq x \leq x_{s}\right) \\
& \frac{\partial p}{\partial x}=\rho_{f} g \sin (\theta) \quad\left(x_{s}<x \leq R\right) .
\end{aligned}
$$




$$
\left|\langle p\rangle-p\left(t, x_{s}, y\right)\right|=\left(H\left(t, x_{s}, y\right) \rho_{s}+\left(1-H\left(t, x_{s}, y\right)\right) \rho_{f}\right) g \sin \alpha x .
$$

Then at the conditions $R / L \ll 1, H_{0}<1$ we can obtain from (15), (26), (27) the following estimations:

$$
\frac{\left|\langle p\rangle-p\left(t, x_{s}, y\right)\right|}{\rho_{s} g|\cos \alpha|\langle H\rangle} \ll 1 ; \quad \frac{\left|\left\langle u_{y}^{1}\right\rangle-u_{y}^{1}\left(t, x_{s}, y\right)\right|}{u_{y}^{1}} \ll 1 .
$$

In this case the terms in the curly brackets in (22)-(26) can be neglected and the governing equations for the averaged variables $N\left(t, x_{s}, y\right)=\langle N\rangle$, $H\left(t, x_{s}, y\right)=\langle H\rangle$ can be written in the form (the averaging signs are omitted):

$$
\begin{aligned}
& \frac{\partial N}{\partial t}+\frac{\partial}{\partial y} N u_{y}^{1}=-k N^{2} \Delta-\frac{N H(1-H)^{2} \delta \rho n g \sin (\theta)}{F x_{s}}, \\
& \frac{\partial H}{\partial t}+\frac{\partial}{\partial y} H u_{y}^{1}=-\frac{H^{2}(1-H)^{2} \delta \rho n g \sin (\theta)}{F x_{s}}, \\
& \frac{\partial}{\partial y}\left[H u_{y}^{1}+(1-H) u_{y}^{2}\right]=0, \\
& H \frac{\partial p}{\partial y}+F\left(u_{y}^{1}-u_{y}^{2}\right)+\rho_{s} n g H \cos (\theta)=0, \\
& (1-H) \frac{\partial p}{\partial y}-F\left(u_{y}^{1}-u_{y}^{2}\right)+\rho_{f} n g(1-H) \cos (\theta)=0 .
\end{aligned}
$$

When $\theta=0$ the system (30) coincides with the corresponding systems in [20, 21]. The second term in the right hand side of the first equation in (30) is responsible for additional aggregation of the particles due to the transversal displacements. In [24] the additional term responsible for the additional aggregation induced by the applied magnetic field was computed as $2 M \delta \chi N H(1-H)^{2} F^{-1} x_{s}$, where $\delta \chi$ is the difference of the magnetic susceptibilities of the particles and fluid, $M$ is the non-dimensional intensity of the ponderomotive force.

With the non-dimensional variables

$$
Y=\frac{y}{L}, \quad T=\frac{t}{T^{*}}, \quad T^{*}=\frac{L}{u_{0}}, \quad u_{0}=\frac{n g \delta \rho w_{0}^{2 / 3}}{\mu_{f}}, W=\frac{w}{w_{0}}, \quad U_{y}^{1}=\frac{u_{y}^{1}}{u_{0}}, \quad K=\frac{k L}{u_{0} w_{0}}
$$

where $T^{*}$ is the characteristic time, $w_{0}$ is the volume of a single particle, the equations for the concentration and volume of the aggregates are the following 


$$
\begin{aligned}
& \frac{\partial W}{\partial T}+U_{y}^{1} \frac{\partial W}{\partial Y}=K H \Delta, \\
& \frac{\partial H}{\partial T}+\frac{\partial}{\partial Y} H U_{y}^{1}=-\frac{H(1-H)^{4,5} W^{2 / 3} \sin (\theta)}{L x_{s}}, \\
& U_{y}^{1}(H, W, Y)=-(1-H)^{4,5} W^{2 / 3} \cos (\theta) .
\end{aligned}
$$

The boundary conditions for the variables are

$$
C(0, Y)=C_{0}, \quad W(0, Y)=1, \quad U^{1}(T, L)=0 .
$$

The system (31) is hyperbolic [20,21] and can be written in the matrix form

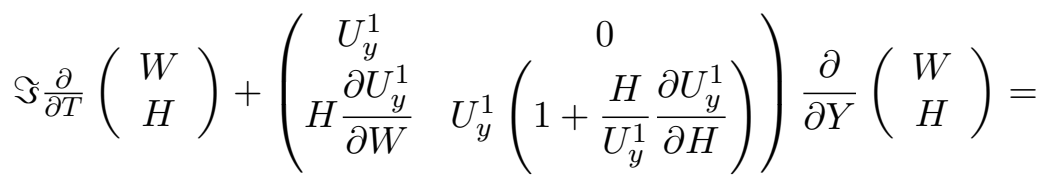

$$
\begin{aligned}
& =\left(\begin{array}{c}
K H \Delta \\
-H \frac{\partial U_{y}^{1}}{\partial Y}-\frac{H(1-H)^{4,5} W^{2 / 3} \sin (\theta)}{L x_{s}}
\end{array}\right),
\end{aligned}
$$

where $\Im$ is the unit matrix

Its characteristic values are

$$
\lambda_{1}=U_{y}^{1}, \quad \lambda_{2}=U_{y}^{1}\left(1+\frac{H}{U_{y}^{1}} \frac{\partial U_{y}^{1}}{\partial H}\right) .
$$

The characteristic equations are

$$
\begin{aligned}
& \text { (I) } \frac{d Y}{d T}=-(1-H)^{4,5} W^{2 / 3} \cos (\theta), \\
& \text { (II) } \frac{d Y}{d T}=A(1-5.5 H) \cos (\theta) .
\end{aligned}
$$

where $A=(1-H)^{3,5} W^{2 / 3}$.

The conditions at the characteristics are

$$
\text { (I) } \frac{d W}{d T}=-K H \Delta
$$

(II) $\frac{d W}{d T}=-\left(\frac{1}{2}+\frac{1}{2(2 H-1) A \cos \alpha}\right) \frac{d H}{d T}+\frac{H(1-H) A \sin (\theta)}{L x_{s}}-1$.

The characteristics of the family (I) have a positive slope, while the family (II) in the physiological range have negative slope. Solution of the one-dimensional problem (31)-(32) can be obtained on (33)-(36) by the method of characteristics. 


\section{Two-dimensional formulation for arbitrary inclination angles.}

In the case of arbitrary finite inclination angle the hyperbolic system of twodimensional equations for and can be obtained from (7)-(8). Supposing the continuity of $\partial p / \partial x$ and $\partial p / \partial y$, the system can be written in the form

$$
\begin{gathered}
\frac{\partial w}{\partial t}+u_{x}^{1} \frac{\partial w}{\partial x}+u_{y}^{1} \frac{\partial w}{\partial y}=k H \\
\frac{\partial H}{\partial t}+u_{x}^{1} \frac{\partial H}{\partial x}+\left(u_{y}^{1}+2 H \Theta^{\prime} \sin (\theta)\right) \frac{\partial H}{\partial y}=0 .
\end{gathered}
$$

This hyperbolic system can be solved by the two-dimensional analogy of the method of characteristics. All the expressions for the bicharacteristics and conditions on them can be obtained on the formulae in [24] by substitution of $\sin (\theta)$ and $\cos (\theta)$ instead of the magnetic field components $\psi_{r}$ and $\psi_{x}$. Then the pressure can be determined from the expressions obtained from (10)-(13)

$$
\frac{\partial p}{\partial x}=\left(H \rho_{s}+(1-H) \rho_{f}\right) G \sin (\theta)
$$

with the boundary conditions

$$
\frac{\partial p}{\partial y}=\left(H \rho_{s}+(1-H) \rho_{f}\right) G \cos (\theta) .
$$

where $p_{a t m}$ is the atmospheric pressure. Solution of the two-dimensional aggregating particle sedimentation problem (7)-(13) can also be found by the particle dynamics method [25].

\section{Numerical results and discussion.}

Like in the case of the vertical tube [20,21], the families of characteristics (I) and (II) have positive and negative slopes accordingly. The family (I) corresponds to the interface between the zones II and III, while the family (II) describes the movement of the interface between the zones I and II moving with the corresponding velocity (20). Numerical computations on (33)-(36) have been carried out using the typical parameters for human blood [20,21]

$$
\begin{aligned}
& H_{0}=0.35 \div 0.5 \mu_{f}=(1.1 \div 1.7) \cdot 10^{-3} \mathrm{~Pa} \cdot \mathrm{s}, G=g, \rho_{f}=1030 \div 1080 \mathrm{~kg} / \mathrm{m}^{3}, \\
& \rho_{s}=1050 \div 1150 \mathrm{~kg} / \mathrm{m}^{3}, L=5 \mathrm{~cm}, R=2 \mathrm{~mm}, \mathrm{k}=10^{-5} \div 10^{-2} \mathrm{~m}^{3} \mathrm{~s}^{-1} .
\end{aligned}
$$

The numerical procedure is described in details in [20,21]. The example of the interface of the software is given in Fig.2. The region confined by the characteristics of different families started at the ends of the tube $Y=0$ and $Y=1$ corresponds to the zone II (Fig.1a). Note the longitudinal coordinate axis in Fig.2 


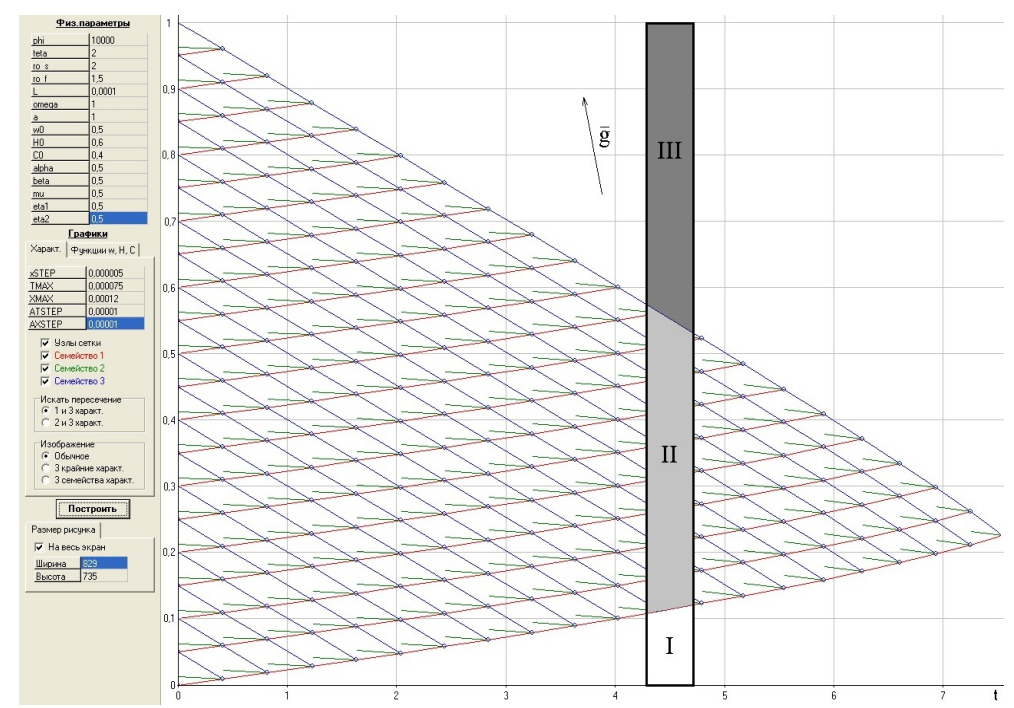

Fig.2. An example of the interface of the software and the zone distribution in the inclined tube: I is the clear fluid zone, II is the zone of sedimenting aggregates, III is the compact zone.

is located in the inverse direction comparatively to the axis in Fig.1. The results of numerical computations are presented in Fig.3-4.

When the applied force increases $(n=1,2,3, \ldots)$, the particles settles faster (Fig.3a). Similar dependence is observed for the suspensions with increasing initial concentration (Fig.3b), aggregation rate (Fig.3c) and small increase in the inclination angle (Fig.3d). The increased external force uniformly accelerates particle sedimentation along the tube and the locations of the interfaces between I and II, II and III changes in a similar way (Fig.3a). When the initial concentration increases, the changes are more noticeable for the I-II interface (Fig.3b). It may be caused by lower viscosities of the suspension at the upper part of the tube that produces lower Stokes forces acting on the surface of the more freely sedimenting aggregates. In the lower part of the zone II the aggregates of the same volume are surrounded my more concentrated suspension with higher viscosity that produced higher Stokes forces hampering the settling of the aggregates towards the $\mathrm{m}$ zone of the sediment III. When particle aggregation rate increases, the changes are more noticeable at the II-III interface (Fig.3c) because in the region with higher concentration the compact zone formation will be very fast. Small increase in the inclination angle significantly accelerates the zone I formation (Fig.3d) because of the decrease of the length the particles move before reaching the lower wall of the inclined tube. When the inclination angle becomes bigger than some critical angle $\theta^{*}$, the sedimentation decelerates. In the case of material parameters used in the computation results presented in Fig. $3 \mathrm{~d} \theta^{*} \sim 8^{\circ}$. The behavior of the particles in the case is similar to those for the granular materials on the inclined surfaces. The inclination shorten the distance each particle must move the reach the lower 
inclined wall that accelerates the sedimentation. When a particle approach the interface II-III and can not longer sediment, it can slide over the interface due to the force $\sim n g \cos (\theta)$ that decreases with increasing the angle. The ability of the settled particle to slide is also confined by the interaction between the neighboring particles that can lead to their aggregation and by higher shear drag for sliding in the concentrated suspension that those in the clear fluid. The increase in the fluid viscosity decelerates the sedimentation but the properties of the particle dynamics remain similar to those presented in Fig.3a-d that confirms physical relevance of the computed results. When $n=1, \theta=0^{\circ}$ the computed curves correspond to those obtained in [21].

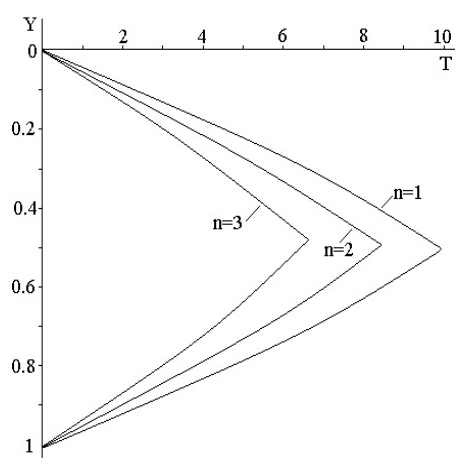

a

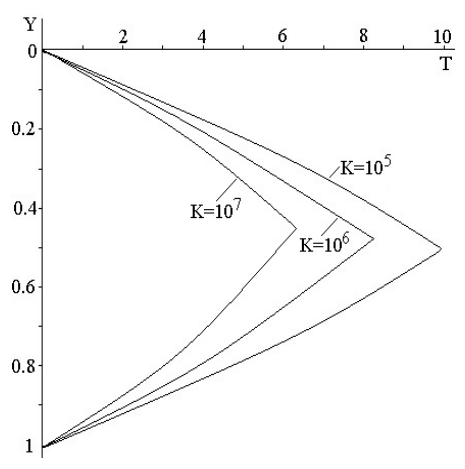

C

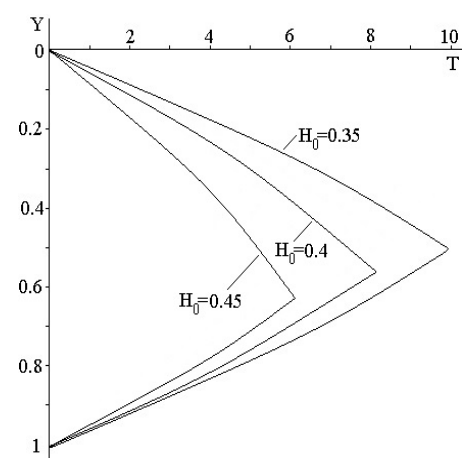

$\mathrm{b}$

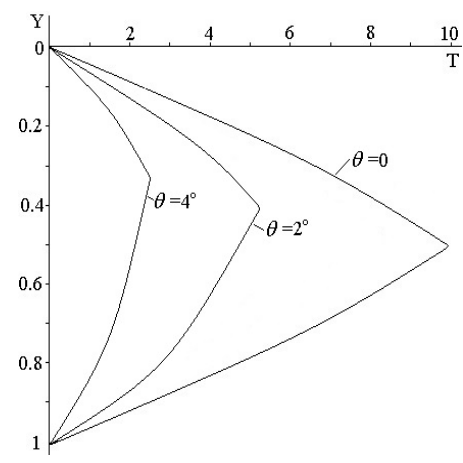

d

Fig.3. Locations of the characteristics at different external force (a), initial concentrations of the particles (b), aggregation rate (c), and inclination angle (d).

$$
T_{\max }=\frac{1}{K H_{0}}\left[\left(\frac{\left.5 K H_{0}\right)}{\left.3\left[1-\gamma\left(H_{0}\right)\right]\left(1-H_{0}\right)^{3.5}\right)}+1\right)^{0.6}-1\right],
$$

where $\gamma(H)=\frac{1-3 H}{1+2 H}+\frac{2.5 H}{1-H}$. 
Since the drag coefficient $F(H, W)$ and aggregation rate $K(H, W, \triangle)$ in the inclined tube could be more complex functions than in the expression (14) which was validated for the vertical tubes [22], (41) can be rewritten in the form

$$
T_{\text {max }}=\frac{1}{K H_{0}}\left[\left(\frac{5 K H_{0} f\left(H_{0}\right)}{\left.3\left[1-\gamma\left(H_{0}\right)\right]\left(1-H_{0}\right)^{3.5}\right)}+1\right)^{0.6}-1\right],
$$

where $f\left(H_{0}\right)$ is the unknown correcting function that is specific for the studied suspension.

When $\theta=0^{\circ}(42)$ must coincide with (41). Based on (42), a novel method for testing the suspension stability of any technical suspension, blood or nanofluid can be proposed. The measurements must be carried out at different inclination angles $\theta=0^{\circ}-10^{\circ}$. In the case of $\theta=0^{\circ}$ (42) allows computation of the basic aggregation rate $k$ by the measured value $T_{\max }$. Then a series of experiments with gradually increasing slop, to say, $\theta=2^{\circ} ; 4^{\circ} ; 6^{\circ} ; 8^{\circ} ; 10^{\circ}$ will give the dependence $f\left(H_{0}\right)$ that can be used for corrections of the expressions in (14) for the inclined tube case. Before decision making upon the nanofluid ageing or blood aggregatability the test must be conducted for the same nanofluid in its basic state before being used for a long time or for the healthy native blood samples. The proposed approach will be tested experimentally in future works.

\section{Conclusions.}

The Boycotte effect which is used in testing of some industrial suspensions is very attractive for usage in the medical diagnostics instead of conventional blood sedimentation test, for investigation of ageing of micro and nanofluids. The developed theory allows easy determination of the sedimentation curves as the moving interfaces I-II and II-III by the method of characteristics. When the inclination angle $\theta=0^{\circ}$ the obtained numerical results and analytical expressions are transformed to the corresponding expressions obtained before for the gravitational sedimentation in the vertical tubes with and without external magnetic field and in the non-uniform centrifugal force field. It was shown, the sedimentation rate increased with increasing the particle concentration, their aggregation rate and external force, but with distinct regularities for the I-II and II-III interfaces. The corresponding dependence on the angle is more complex. Sedimentation is accelerated by small angles but at the angles exceeded some critical value the settling is decelerated and hampered. That can be explained by the initial faster settling followed by deceleration of sliding of the particles along the inclined wall by the shear drag. Based on the obtained results, a novel method of determination not only the aggregation ability of the particles but also the particle-specific and angle-dependent shear stress factor is proposed. The experimental validation of the proposed approach will be tested in our future experimental studies on blood and different types of nanofluids used in the microfluidic flow systems. 
ORCID ID

V. Baranets (iD https://orcid.org/0000-0001-6386-3207

N. Kizilova (iD https://orcid.org/0000-0001-9981-7616

\section{REFERENCES}

1. A. E. Boycott. Sedimentation of blood corpuscles, Nature, - 1920. -- V. 104, $532 \mathrm{p}$.

2. S.A.P. Moys. Sedimentation of polydisperse particles at low Reynolds numbers in inclined geometries, $\mathrm{PhD}$ Thesis. Santiago de Chile, 2016. - 78 p.

3. P. Hanson, T. Trigg, G. Rachal, M. Zamora. Investigation of Barite Sag in Weighted Drilling Fluids in Higlu Deviated Wells, SPE paper 20423 presented at the SPE Annual Conference and Exhibition, New Orlean, 1990. - Sept. P. 23-26.

4. J. Duran, T. Mazozi. Granular boycott effect: how to mix granulates, Phys Rev E Stat Phys Plasmas Fluids Relat Interdiscip Topics, 1999. - Nov. — 60 (5 Pt B):6199 - 201 p.

5. T. Peacock, F. Blanchette, J. W. M. Bush. The stratified Boycott effect, J. Fluid Mech, 2005. - 529. - P. 33-49.

6. R.S. MacTaggart, D.H-S. Law, J.H. Masliyah, K. Nandakumar. Gravity separation of concentrated bidisperse suspensions in inclined plate settlers, Intern. J. Multiphase Flow, 1988. - 14(4):519. - 532 p.

7. E. Fukada, T. Azuma. Erythrocyte sedimentation rate II. Effects of tilt angle in saline solution, Biorheology, 1988. - 1-2. V. 25. - P. 157-164.

8. A. Acrivos, E. Herbolzheimer. Enhanced sedimentation in settling tanks with inclined walls, J. Fluid Mech., 1979. — 3. V. 92. - P. 435-457.

9. H. Lamb. Hydrodynamics, 1932. Cambridge University Press.

10. Eric Ponder. On Sedimentation and rouleaux formation, Experimental Physiology, 1926. - 2. V. 16. - P. 173-194.

11. N. Nakamura, K. Kuroda. La cause de l'acceleration de la vitesse de sedimentation des suspensions dans les recipients inclines, Keijo J. Med., 1937. V. 8. - P. 256-296.

12. W. D. Hill, R. R. Rothfus, K. Li. Boundary-enhanced sedimentation due to settling convection, Int. J. Multiphase Flow, 1977. - V. 3. - P. 561-583.

13. R. F. Probstein, R. E. Hicks. Lamella settlers: a new operating mode for high performance, Ind. Water Eng., 1978. - V. 15. - P. 6-8. 
14. I. Rubinstein. A steady laminar flow of a suspension in a channel, International Journal of Multiphase Flow, 1980. - 5. V. 6. - P. 473-490.

15. W. F. Leung, R. F. Probstein. Lamella and tube settlers. 1. Model and operation, Industrial \& Engineering Chemistry Process Design and Development, 1983. - 1. V. 22. - P. 58-67.

16. Y. Toyama, T. Dobashi, A. Sakanishi, S. Oka. Enhanced erythrocyte sedimentation rate and upflow layer in inclined rectangular vessel, Jap. J. Appl. Phys., 1990. - 2. V. 29. - P. 453-454.

17. J. Zhang, Q. Guo, M. Liu, J. Yang. A lab-on-CD prototype for high-speed blood separation, J. Micromech. Microeng., 2008. - 12. V. 18:125025.

18. S. Chakraborty. Microfluidics and Microscale Transport Processes, 2012. CRC Press., -366 p.

19. Z.-J. Xu, E.E. Michaelides. A Numerical Simulation of the Boycott Effect, Chemical Engineering Communic., 2005. - 4. V. 192. - P. 532-549.

20. N. Kizilova, L. Batyuk, V. Cherevko. Human Red Blood Cell Properties and Sedimentation Rate: a Biomechanical Study, Biomechanics in Medicine and Biology: Proceedings of the International Conference of the Polish Society of Biomechanics, Zielona Gora, 2018. - September 5-7. - Poland. K. Arkusz, R. Bedzinski, T. Klekiel, S. Piszczatowski, eds. Springer Series "Advances in Intelligent Systems and Computing." - V. 831, - 2019. - P. 3-22.

21. N. N. Kizilova, V.A. Cherevko. Gravitational sedimentation of erythrocytes: experiments and theoretical model, Visnyk of V.N. Karazin Kharkiv National University. Ser. Mathematics, Applied Mathematics and Mechanics, 2009. V. 875. - P. 80-94.

22. Y.S. Losev. Some problems of hydromechanics of suspensions with varying densities: application to the blood. PhD Thesis, 1984. - Moscow University. $-135 \mathrm{p}$.

23. O. M. Datsok, Ye. N. Zholonsky, N. N. Kizilova. Two-phase model of the erythrocytes sedimentation in a non-uniform force field, Visnyk Kharkov Polytechnic University, 2002. - V. 135. - P. 61-66.

24. N. N. Kizilova. Effect of radial motion of erythrocytes on their sedimentation in a tube in an external magnetic field, Fluid Dynamics, 1991. - 5. V. 26. P. 737-744.

25. V.A. Baranets, N. N. Kizilova. Discrete modeling of aggregation and sedimentation of nanoparticles in suspensions, Visnyk of V.N. Karazin Kharkov National University. Ser. "Mathematical modeling. Information technologies. Automated control systems", 2018. - V. 38. 
V. Baranets, N. Kizilova. Mathematical modeling of particle aggregation and sedimentation in the inclined tubes. Sedimentation of the aggregating particles in the gravity field is widely used as an easy and cheap test of the suspension stability of different technical suspensions, blood and nanofluids. It was established the tube inclination makes the test much faster that is known as the Boycott effect. It is especially important for the very slow aggregating and sedimenting blood samples in medical diagnostics or checking the ageing of the nanofluids. The dependence of the sedimentation rate on the angle of inclination is complex and poorly understood yet. In this paper the two phase model of the aggregating particles is generalized to the inclined tubes. The problem is formulated in the two-dimensional case that corresponds to the narrow rectangle vessels or gaps of the viscosimeters of the cone-cone type. In the suggestion of small angles of inclination the equations are averaged over the transverse coordinate and the obtained hyperbolic system of equations for is solved by the method of characteristics. During the sedimentation the upper region (I) of the fluid free of particles, the bottom region (III) of the compactly located aggregates without fluid, and the intermediate region of the sedimenting aggregates (II) appear. The interface between I and II can be registered by any optic sensor and its trajectory is the sedimentation curve. Numerical computations revealed the increase in the initial concentration of the particles, their aggregation rate, external uniform force and inclination angle accelerate the sedimentation while any increase in the fluid viscosity decelerates it that is physically relevant. Anyway, the behaviors of the acceleration are different. For the elevated force the interfaces I-II and IIIII shifts uniformly, while for the elevated concentration or aggregation rate the interface I-II or II-III moves faster. Small increase of the inclination angle accelerates the sedimentation while at some critical angles is starts to decelerate due to higher shear drag in the very viscous mass of the compactly located aggregates. Based on the results, a novel method of estimation of the suspension stability is proposed.

Keywords: Boycott effect; suspension; aggregation; sedimentation; medical diagnostics.

Баранець В. О., Кізілова Н. М. Математичне моделювання агрегації та осідання частинок в похилих трубках. Осідання агрегуючих частинок у гравітаційному полі широко використовується як простий і дешевий тест на стабільність суспензії різних технічних сумішей, крові та нанорідин. Встановлено, що нахил трубки робить тест набагато швидшим, що відомо як ефект Бойкотта. Це особливо важливо для дуже повільного агрегуючих та осідаючих зразків крові в медичній діагностиці або перевірки старіння нанорідин. Залежність швидкості осідання від кута нахилу є складною і мало вивченою задачею. У цій роботі узагальнено двофазну модель агрегуючих частинок у похилих трубках. Задача сформульована в двовимірному випадку, що відповідає вузьким прямокутним ємностям або зазорам віскозиметрів конусоподібного типу. У припущенні малих кутів нахилу рівняння усереднюються по поперечній координаті, а отримана гіперболічна система рівнянь розв'язується методом характеристик. Під час осідання з'являється верхня область рідини, вільної від частинок (I), нижня область компактно розташованих агрегатів без рідини(III) і проміжна область осідаючих агрегатів (II). Границя поділу між I та II областями може бути зареєстрована будь-яким оптичним датчиком, а його траєкторія $є$ кривою осідання. Чисельні розрахунки виявили, що збільшення початкової концентрації частинок, їх швидкості агрегації, зовнішньої рівномірної сили і кута нахилу прискорюють осідання, а будь-яке зростання в'язкості рідини сповільнює його, що є фізично доречним. Так чи інакше, поведінка прискорення різна. При зростанні сили границі поділу між зонами I-II і II-III пересуваються рівномірно, тоді як при збільшенні концентрації або швидкості агрегації - рухаються швидше. При невеликому 
збільшенні кута нахилу осідання прискорюється, а при деяких критичних кутах починає сповільнюватися внаслідок більш високого зсувного опору в дуже в'язкій масі компактно розташованих агрегатів. На основі отриманих результатів запропоновано новий метод оцінки стійкості суспензії.

Ключові слова: ефект Бойкотта; суспензія; агрегація; седиментація; медична діагностика.

Article history: Received: 14 April 2019; Final form: 22 April 2019; Accepted: 1 November 2019. 